Bull. Fac. Agric., Cairo Univ., 59 (2008): 318 - 325.

\title{
INSECT FAUNA OF ONION PLANTS IN SEEDBEDS, FIELDS AND STORES IN ASSIUT GOVERNORATE
}

\author{
(Received: 3.4.2008)
}

\author{
By \\ S.I. El-Sherif and H.H. Mahmoud*

\begin{abstract}
Department of Economic Entomology and Pesticides, Faculty of Agriculture, Cairo University, Giza, Egypt and * Plant Protection Research Institute, Agricultural Research Center, Ministry of Agriculture, Giza, Egypt
\end{abstract}

\begin{abstract}
The survey of the insect fauna associated with onion seedbeds and fields during 2002/2003 revealed 32 species belonging to 27 families and 11 orders. Among these species 22 were pests belonging to 20 families and 6 orders, 8 were predators belonging to 5 families and 4 orders and 2 were parasites belonging to the family Braconidae from order Hymenoptera. Insects associated with stored onion bulbs during 2003 storage season were 13 species belonging to 11 families and 5 orders among which 10 were pests belonging to 7 families and 3 orders, 2 were predators belonging to 2 families and 2 orders and only 1 parasite species belonging to the family Chalcididae, order Hymenoptera. Insect species are systematically listed in tables showing their existing stage(s), frequency and period of occurrence. The most destructive and commonly occurring insect pest in onion seedbeds and fields was the onion thrips Thrips tabaci Lindeman (Thysanoptera : Thripidae) which prevailed from October till May. The larvae of the onion bulb fly Eumerus amoenus Loew. (Diptera: Syrphidae) were the most serious pest threatening stored onion bulbs throughout the storage period that extended from early June until early November.
\end{abstract}

Key words: insect fauna, onion seedbeds and fields, onion stores.

\section{INTRODUCTION}

Onion is cultivated in several governorates especially in Upper Egypt. Usually, onion seedbeds are seeded in August and September, transplanted in October and November then harvested by next April or May and stored from June until November.

Literature on the insects associated with onion plantations and stored onion bulbs in Egypt refer to El-Sherif (1971) and Haydar \& Sherif (1987) at Giza, Abd-El-Fattah (1980) at Giza and Sohag, ElBolok et al. (1990) at Giza and Assiut and AbdEl-Wahab (2004) for onion plantations and the studies of Ibrahim et al. (1970) and Aboul-Zahab (1976) at Alexandria, Abd-El-Fattah (1980) at Giza and Sohag, Marei (1985) at Giza and ElBolok et al. (1990) at Giza and Assiut for stored onion bulbs. Abroad, literature refer to Thiramurthi et al. (1989) and Gupta et al. (1991) in India, Ahn et al. (1991) in Korea, Szwejda (1998 \& 2005) in Poland, Ciociola et al. (2002) in Brazil, Duchovskiene (2003) in Lithuania, Chernenko \&Chernenko (2004) in Ukraine and Mesic \& Baric (2004) in Croatia. Contributions on the insect fauna associated with stored onion bulbs abroad were given by Klein-Krautheim (1934) from Germany, Aihara et al. (1985) from Japan, Marcos-Garcia (1990) from Spain, Gupta et al. (1991) from India and Paulauskyte (1999) from Lithuania.

The present investigation is a survey of such fauna in Assiut Governorate which is one of the major onion production areas, throughout a complete onion growing and storage season.

\section{MATERIALS AND METHODS}

The survey was carried out in farmers seedbeds and fields cultivated with the commonly planted onion cultivar "Giza 6 Mohassan" at different localities of Assiut Governorate from September 2002 until May 2003. Random samples of 100 seedlings or plants were carefully pulled off from selected seedbeds and fields in the late afternoon (between 3 and 5 p.m.). Sampling in the early morning, which is a common practice in insect surveys, was avoided because onion plants are usually covered with dense dew by early morning. Sampling was practiced at 15-day intervals and sampled plants were carefully introduced into cloth bags then transferred to the 
laboratory for inspection. In addition to the plant samples, 40 full-length double-net strokes were also taken across the two diagonals of randomly selected parts of the examined onion seedbeds and fields (about $350 \mathrm{~m}^{2}$ ) at every sampling date. Net catch was killed in an ordinary cyanide jar then transferred to the laboratory for inspection. Insects captured through both plant samples and net-sweeps were carefully examined for identification. In the case of uncertain taxonomic identification(s) the suspected specimens were conveyed to the appropriate specialist(s) of Insect Classification Research Department at the Plant Protection Research Institute, ARC, Dokki, Giza for proper identification.

Quantities of bulbs of onion cultivar Giza 6 Mohassan were collected at harvest time at Assiut Governorate and heaped on the floor of selected stores measuring $6.0 \mathrm{~m}$. long x $4.0 \mathrm{~m}$. wide $\mathrm{x} 3.5 \mathrm{~m}$. high provided with suitable ventilation opennings covered with narrowmeshed wire-gauze. Throughout the period extending from early June until early November 2003 a random sample of 100 bulbs was taken every two weeks from every store and carefully examined for insect infestation and identification.

\section{RUSULTS AND DISCUSSION \\ 3.1. Insects associated with onion seedbeds and fields}

The survey in Table (1) reveals 32 species belonging to 27 families and 11 orders. Among these species 22 were pests belonging to 20 families and 6 orders, 8 were predators belonging to 5 families and 4 orders and 2 were Hymenopterous parasites belonging to the family Braconidae.

In Egypt, Abd-El-Fattah (1980) surveyed 21 insect species on onion plants at Giza and Sohag Governorates and El-Bolok et al. (1990) found that at Giza and Assiut Governorates onion plantations were inhabited by a variety of insects belonging to 38 genera from 23 families and 9 orders. Thiramurthi et al. (1989) reported 10 species of insects on onion flowers in India and Ahn et al. (1991) surveyed the insect pests in onion fields in Korea. In Poland, Szwejda (1998\&2005) identified 23 insect species from onion fields. Ciociola et al. (2002) gave notes on the insect pests of onions in Brazil. Duchovskiene (2003) reported 11 insect species from onion plantations in Lithuania and Mesic\&Baric (2004) listed the Dipterous pests associated with onion plants in Croatia.

Frequent observations emphasized that the larvae and adults of the cotton or onion thrips Thrips tabaci Lind. (Thysanoptera : Thripidae) are the sole commonly occurring and economically important insect pests in onion seedbeds and fields throughout the whole onion growing season (November - May). Such observations seem to coincide with the findings of El-Sherif (1971), Khalil et al. (1971), Haydar and Sherif (1987) and Abd-El-Wahab (2004) who agreed that Thrips tabaci is a dominant insect species in onion plantations in Egypt. Some other studies referred to Thrips tabaci as a major pest in onion plantations in India (Thiramurthi et al., 1989 \&Gupta et al., 1991), Korea (Ahn et al. ,1991), Poland (Szwejda, 1998 \& 2005), Brazil (Ciociola et al., 2002) and Lithuania (Duchovskiene, 2003).

As seen in Table (1), five insect species were of frequent occurrence in onion seedbeds and fields. Two of these species occurred as nymphs and adults during spring namely: the cotton aphid Aphis gossypii (Homoptera: Aphididae) from March to May and the leaf hopper Empoasca discipiens (Homoptera: Cicadellidae) during March and April. Another frequently occurring pest was the onion bulb fly Eumerus aamoenus (Diptera: Syrphidae) which was recorded mainly as larvae but occasionally as pupae throughout May. The remaining two frequently occurring species were the stable fly Lyperrosia minuta (Diptera: Muscidae) and the lesser tachina fly Actia carssicornis (Diptera: Tachinidae) which were recorded as adults only from February until April.

Table (1) further indicates that the adults of the grasshopper Euprepocnemis plorans (Orthoptera: Acridiidae) and the kidney bean blotch leaf miner Melanagromyza cunctans (Diptera: Agromyzidae) were rare in onion seedbeds and fields throughout winter and spring. (November - April). In addition, the adults of six other pests were also rare in onion fields during spring (February - April) namely: the cotton and tomato whitefly Bemisia tabaci (Homoptera: Aleyrodidae), the dolichopodid fly Dolichopus diadema (Diptera: Dolichopodidae), the rice root midge Ephydra macellaria (Diptera: Ephydridae), the rice leaf miner Hydrellia griseola (Diptera: Ephydridae), the rice whorl maggot Hydrellia modesta (Diptera: Ephydridae) and the streams fly Melieria nigritarsis (Diptera: Otitidae). Thus, the total number of few pests recorded eight. 
Table (1): Insect fauna associated with onion seedbeds and fields.

\begin{tabular}{|c|c|c|c|c|}
\hline No. & Species & Stage(s) & $\begin{array}{c}\text { Frequency of } \\
\text { occurrence }\end{array}$ & $\begin{array}{l}\text { Period of } \\
\text { occurrence }\end{array}$ \\
\hline \multicolumn{5}{|c|}{$\begin{array}{lllll}\mathbf{P} & \mathbf{E} & \mathbf{S} & \mathbf{T} & \mathbf{S} \\
\end{array}$} \\
\hline 1 & $\begin{array}{l}\text { Thrips tabaci Lind. } \\
\text { (Thysanoptera : Thripidae) }\end{array}$ & $A \& L$ & $\mathrm{C}$ & Nov. - May \\
\hline 2 & $\begin{array}{l}\text { Aphis gossypii Glover } \\
\text { (Homoptera : Aphidiae) }\end{array}$ & $A \& N$ & $\mathrm{Fr}$ & Mar. - May \\
\hline 3 & $\begin{array}{l}\text { Empoasca discipiens Paoli } \\
\text { (Homoptera : Cicadellidae) }\end{array}$ & $A \& N$ & Fr & Mar. - Apr. \\
\hline 4 & $\begin{array}{l}\text { Lyperosia minuta Bezzi } \\
\text { (Diptera : Muscidae) }\end{array}$ & A & Fr & Feb. - Apr. \\
\hline 5 & $\begin{array}{l}\text { Eumerus amoenus Loew. } \\
\text { (Diptera : Syrphidae) }\end{array}$ & $\mathrm{L} \& \mathrm{P}$ & $\mathrm{Fr}$ & May \\
\hline 6 & $\begin{array}{l}\text { Actia crassicornis (Meigen) } \\
\text { (Diptera : Tachinidae) }\end{array}$ & A & Fr & Feb. - Apr. \\
\hline 7 & $\begin{array}{l}\text { Euprepocnemis plorans (Charp.) } \\
\text { (Orthoptera : Acridiidae) }\end{array}$ & A & $\mathrm{Fe}$ & Nov. - Apr. \\
\hline 8 & $\begin{array}{l}\text { Bemisia tabaci (Gennadius) } \\
\text { (Homoptera : Aleyrodidae) }\end{array}$ & A & $\mathrm{Fe}$ & Feb. - Apr. \\
\hline 9 & $\begin{array}{l}\text { Melanagromyza cunctans(Meigen) } \\
\text { (Diptera : Agromyzidae) }\end{array}$ & A & $\mathrm{Fe}$ & Nov. - Mar. \\
\hline 10 & $\begin{array}{l}\text { Dolichopus diadema Halidany } \\
\text { (Diptera : Dolichopodidae) }\end{array}$ & A & $\mathrm{Fe}$ & Mar. - Apr. \\
\hline 11 & $\begin{array}{l}\text { Ephydra macellaria Eggr } \\
\text { (Diptera : Ephydridae) }\end{array}$ & A & $\mathrm{Fe}$ & Feb. - Apr. \\
\hline 12 & $\begin{array}{l}\text { Hydrellia griseola Fallen } \\
\text { (Diptera : Ephydridae) }\end{array}$ & A & $\mathrm{Fe}$ & Feb. - Mar. \\
\hline 13 & $\begin{array}{l}\text { Hydrellia modesta Loew. } \\
\text { (Diptera : Ephydridae) }\end{array}$ & A & $\mathrm{Fe}$ & Mar. - Apr. \\
\hline 14 & $\begin{array}{l}\text { Melieria nigritarsis Becker } \\
\text { (Diptera : Otitidae) }\end{array}$ & A & $\mathrm{Fe}$ & Mar. - Apr. \\
\hline 15 & $\begin{array}{l}\text { Lepidocentinus insertus Handschin } \\
\text { (Collembola : Entombryidae) }\end{array}$ & A & $\mathrm{R}$ & Mar. \\
\hline 16 & $\begin{array}{l}\text { Delia alliaria Fonseca } \\
\text { (Diptera : Anthomyiidae) }\end{array}$ & A & $\mathrm{R}$ & Mar. \\
\hline 17 & $\begin{array}{l}\text { Sciara kairensis Becker } \\
\text { (Diptera : Sciaridae) }\end{array}$ & A & $\mathrm{R}$ & Feb. \\
\hline 18 & $\begin{array}{l}\text { Tachys gilvus Sch. } \\
\text { (Coleoptera : Carabidae) }\end{array}$ & A & $\mathrm{R}$ & Mar. \\
\hline 19 & $\begin{array}{l}\text { Cryptophagus affinis Strm. } \\
\text { (Coleoptera :Cryptophagidae) }\end{array}$ & A & $\mathrm{R}$ & Mar. - Apr. \\
\hline 20 & $\begin{array}{l}\text { Sitona lividipes Fahrs. } \\
\text { (Coleoptera : Curculionidae) }\end{array}$ & A & $\mathrm{R}$ & Mar. - Apr. \\
\hline 21 & $\begin{array}{l}\text { Drasterius figuratus Germ. } \\
\text { (Coleoptera : Elateridae) }\end{array}$ & A & $\mathrm{R}$ & Apr. \\
\hline 22 & $\begin{array}{l}\text { Aphodius sicardi } \text { Rtt. } \\
\text { (Coleoptera : Scarabacidae) }\end{array}$ & A & $\mathrm{R}$ & Apr. \\
\hline
\end{tabular}


Table (1). Continued

\begin{tabular}{|c|c|c|c|c|}
\hline No. & Species & Stage(s) & $\begin{array}{l}\text { Frequency of } \\
\text { occurrence }\end{array}$ & $\begin{array}{l}\text { Period of } \\
\text { occurrence }\end{array}$ \\
\hline \multicolumn{5}{|c|}{ PREDATOR S } \\
\hline 1 & $\begin{array}{l}\text { Hemianax ephippiger Selys. } \\
\text { (Odonata : Aeschnidae) }\end{array}$ & A & $\mathrm{R}$ & Feb. - Apr. \\
\hline 2 & $\begin{array}{l}\text { Chrysoperla carnea Steph. } \\
\text { (Neuroptera : Chrvsopidae) }\end{array}$ & A & $\mathrm{R}$ & Mar. - Apr. \\
\hline 3 & $\begin{array}{l}\text { Syrphus corollae Fabricius } \\
\text { (Diptera: Svrohidae) }\end{array}$ & A & $\mathrm{R}$ & Mar. \\
\hline 4 & $\begin{array}{l}\text { Scymnus interruptus Ws. } \\
\text { (Coleoptera : Coccinellidae) }\end{array}$ & A & $\mathrm{R}$ & Apr. \\
\hline 5 & $\begin{array}{l}\text { Scymnus pallidivestis Sit. } \\
\text { (Coleoptera : Coccinellidae) }\end{array}$ & A & $\mathrm{R}$ & Apr. \\
\hline 6 & $\begin{array}{l}\text { Coccinella undecimpunctata L. } \\
\text { (Coleoptera : Coccinellidae) }\end{array}$ & $A \& L$ & $\mathrm{R}$ & Mar. - Apr. \\
\hline 7 & $\begin{array}{l}\text { Scymnus punctillum Weise } \\
\text { (Coleoptera : Coccinellidae) }\end{array}$ & A & $\mathrm{R}$ & Mar. - Apr. \\
\hline 8 & $\begin{array}{l}\text { Paederus alfierii Koch } \\
\text { (Coleoptera : Staphylinidae) }\end{array}$ & A & $\mathrm{R}$ & Apr. \\
\hline \multicolumn{5}{|c|}{ PARAS I T ES } \\
\hline 1 & $\begin{array}{l}\text { Opius concolor Silvestri } \\
\text { (Hymenoptera : Braconidae) }\end{array}$ & A & $\mathrm{Fe}$ & Feb. - Mar. \\
\hline 2 & $\begin{array}{l}\text { Diaeretiella rapae (M'Intoch) } \\
\text { (Hymenoptera : Braconidae) }\end{array}$ & A & $\mathrm{R}$ & Mar. \\
\hline
\end{tabular}

The adults of another group of pests comprising eight species were of rare occurrence in onion fields throughout early spring (March April). This group included the cotton springtail Lepidocentinus insertus (Collembola: Entombryidae), the onion maggot Delia alliaria (Diptera: Anthomyiidae), the hogweed umbels Sciara kairensis (Diptera: Sciaridae), the ground beetles Tachys gilvus (Coleoptera: Carabidae), the dried fruit beetle Cryptophagus affinis (Coleoptera: Cryptophagidae), the clover root weevil Sitona lividipes (Coleoptera: Curculionidae), the clicker beetle Drasterius figuratus (Coleoptera: Elateridae), and the dung beetle Aphodius sicardi (Coleoptera: Scarabacidae).

As seen in Table (1), survey results revealed the rare occurrence of only eight predator species mostly by early spring (March - April). These predators are the dragonfly Hemianax ephippiger (Odonata: Aeschnidae), the aphid lion Chrysoperla carnea (Neuroptera: Chrysopidae), the syrphus fly Syrphus corollae (Diptera: Syrphidae), the ladybird beetles Scymnus interruptus, Scymnus punctillum and Scymnus pallidivestis (Coleoptera: Coccinellidae), the eleven spots beetle Coccinella undecimpunctata (Coleoptera: Coccinellidae), and the orange rove beetle Paederus alfierii (Coleoptera: Staphylinidae). All of these predators occurred as adults only except for Coccinella undecimpunctata which occurred as both larvae and adults. It is noteworthy to mention here that two mites; Cheiracanthium sp. (Araneida: Miturgidae) and Thanatus sp. (Araneida: Philodromidae), were observed as active predators in onion fields. As for the parasites occurring in onion plantations, the current survey revealed the adults of only two Hymenopterous species from the family Braconidae; Opius concolor and Diaeretiella rapae. The former parasite was of few occurrence in February and March while the latter rarely occurred throughout March.

Reviewing the previous surveys of the insect fauna associated with onion plantations at the different governorates of Egypt (El-Sherif, 1971; Abd-El-Fattah, 1980; El-Bolok et al., 1990 and 
Abd-El-Wahab, 2004) revealed 45 species. Among these the current survey confirmed the occurrence of only 12 species namely: Hemianax ephippiger, Euprepocnemis plorans, Aphis gossypii, Bemisia tabaci, Empoasca discipiens, Thrips tabaci:, Chrysoperla carnea, Eumerus amoenus, Delia alliaria, Coccinella undecimpunctata, Scymnus punctillum and Paederus alfierii .This leads to the anticipation that 20 out of the 32 species surveyed through the current survey are, probably, new records from onion seedbeds and fields. These new records include Lepidocentinus insertus, Lyperosia minuta, Actia crassicornis, Melanagromyza cunctans, Dolichopus diadema, Ephydra macellaria, Hydrellia griseola, Hydrellia modesta, Melieria nigritarsis, Sciara kairensis, Syrphus corollae, Opius concolor, Diaeretiella rapae, Tachys gilvus, Cryptophagus affinis, Sitona lividipes, Drasterius figuratus, Aphodius sicardi, Scymnus interruptus and Scymnus pallidivestis. It is most probable, however, that some of these new records are neither pests nor natural enemies but visitors that accidentally occurred in onion seedbeds and / or fields.

\subsection{Insects associated with stored onion bulbs}

The survey of the insect fauna associated with onion bulbs in stores at Assiut Governorate during 2003 storage season revealed 13 insects species belonging to 11 families and 5 orders (Table, 2). The most commonly occurring insect pest on onion bulbs was the onion bulb fly Eumerus amoenus (Diptera: Syrphidae) which was observed as larvae and pupae infesting bulbs from early June until early November which agrees with (El-Bolok et al., 1990) \& (El-Shabrawy, 1996). Four insect pests frequently occurred on stored onion bulbs; Eumerus vestitus (Diptera:

Table (2): Insect fauna associated with stored onion bulbs.

\begin{tabular}{|c|c|c|c|c|}
\hline No. & Species & Stage(s) & $\begin{array}{c}\text { Frequency of } \\
\text { occurrence }\end{array}$ & $\begin{array}{c}\text { Period of } \\
\text { occurrence }\end{array}$ \\
\hline \multicolumn{5}{|c|}{$\begin{array}{lllll}\mathbf{P} & \mathbf{E} & \mathbf{S} & \mathbf{T} & \mathbf{S} \\
\end{array}$} \\
\hline 1 & $\begin{array}{l}\text { Eumerus amoenus Loew. } \\
\text { (Diptera : Syrphidae) }\end{array}$ & L\&P & $\mathrm{C}$ & Jun. - Nov. \\
\hline 2 & $\begin{array}{l}\text { Cadra cautella Walker } \\
\text { (Lepidoptera : Pyralidae) }\end{array}$ & L\&P & Fr & Jun. - Oct. \\
\hline 3 & $\begin{array}{l}\text { Eumerus vestitus Bez. } \\
\text { (Diptera : Syrphidae) }\end{array}$ & L\&P & Fr & Jul. - Oct. \\
\hline 4 & $\begin{array}{l}\text { Atherigona orientalis Schin } \\
\text { (Diptera : Syrphidae) }\end{array}$ & L\&P & Fr & Jul. - Oct. \\
\hline 5 & $\begin{array}{l}\text { Carpophilus humeralis } \mathrm{F} . \\
\text { (Coleoptera : Nitidulidae) }\end{array}$ & A\&L\&P & Fr & Jun. - Oct. \\
\hline 6 & $\begin{array}{l}\text { Musca domestica } \mathrm{L} . \\
\text { (Diptera : Muscidae) }\end{array}$ & $\mathrm{L}$ & $\mathrm{Fe}$ & Jun. - Oct. \\
\hline 7 & $\begin{array}{l}\text { Carpophilus immaculatus Luc. } \\
\text { (Coleoptera : Nitidulidae) }\end{array}$ & A & $\mathrm{Fe}$ & Jun. - Oct. \\
\hline 8 & $\begin{array}{l}\text { Sciara kairensis Becker } \\
\text { (Diptera : Sciaridae) }\end{array}$ & A & $\mathrm{R}$ & Aug. - Sep. \\
\hline 9 & $\begin{array}{l}\text { Saprinus chalcites Illiger } \\
\text { (Coleoptera : Histeridae) }\end{array}$ & A & $\mathrm{R}$ & Oct. \\
\hline 10 & $\begin{array}{l}\text { Clitobius oblongiusculus Feh. } \\
\text { (Coleoptera : Tenebrionidae) }\end{array}$ & A & $\mathrm{R}$ & Jun. \\
\hline \multicolumn{5}{|c|}{ PREDATORS } \\
\hline 1 & $\begin{array}{l}\text { Xylocoris galactinus Fieber } \\
\text { (Hemiptera : Anthocoridae) }\end{array}$ & $A \& N$ & Fr & Jun. - Oct. \\
\hline 2 & $\begin{array}{l}\text { Paederus alfierii Kock. } \\
\text { (Coleoptera : Staphylinidae) }\end{array}$ & A & $\mathrm{R}$ & Aug. \\
\hline \multicolumn{5}{|c|}{ P A RAS I T ES } \\
\hline 1 & $\begin{array}{l}\text { Dirhinoides wohlfahrtia Ferrier } \\
\text { (Hymenoptera : Chalcididae) }\end{array}$ & $\mathrm{A}$ & Fr & Jul. - Oct. \\
\hline & $\begin{array}{cll}\mathrm{N}=\text { Nymphs } & \mathrm{L}=\text { Larvae } & \mathrm{P}=\text { Pupae } \\
\mathrm{C}=\text { Common } & \mathrm{Fr}=\text { Frequent } & \mathrm{Fe}=\mathrm{Few}\end{array}$ & $\begin{array}{l}\text { A }=\text { Adults } \\
\mathrm{R}=\text { Rare }\end{array}$ & & \\
\hline
\end{tabular}


Syrphidae), Atherigona orientalis (Diptera: Syrphidae), Cadra cautella (Lepidoptera: Pyralidae) and Carpophilus humeralis (Coleoptera: Nitidulidae) which occurred from June until October.Eumerus vestitus, Atherigona orientalis and Cadra cautella were observed as both larvae and pupae while Carpophilus humeralis occurred as larvae, pupae and adults.

Two other pests were rare; the larvae of Musca domestica (Diptera: Muscidae) and the adults of Carpophilus immaculatus (Coleoptera: Nitidulidae). The adults of three other pests namely: Sciara kairensis (Diptera: Sciaridae), Saprinus chalcites (Coleoptera: Histeridae) and Clitobius oblongiusculus (Coleoptera: Tenebrionidae) were of rare occurrence on stored onion bulbs. Sciara kairensis occurred in August and September while Clitobius oblongiusculus and Saprinus chalcites occurred throughout June and October, respectively.

Two predator species were associated with stored onion bulbs; Xylocoris galactinus (Hemiptera: Anthocoridae) which frequently occurred from June until October and Paederus alfierii (Coleoptera: Staphylinidae) which was rarely seen throughout August. Also, the adults of the parasite Dirhinoides wohlfahrtia (Hymenoptera: Chalcididae) were of frequent occurrence on stored onion bulbs from early July until the end of October. In addition to the abovementioned predators and parasite two predator mites; Rhizoglyphus robini Claparede and Tyrophagus putrescentiae Schrank (Acariformes: Acaridae) were frequently seen associated with stored onion bulbs throughout the whole storage period.

Previous records of the insect fauna associated with onion bulbs in store in Egypt reported 28 species most of which are stored product pests. These species are: Acheta domesticus, Labidura reparia, Xylocoris galactinus, Cryptoblabes gnidiella, Ephestia (Anagasta) kuehniella, Eumerus amoenus, Eumerus vestitus, Atherigona orientalis, Delia alliaria, Drosophila melanogaster, Musca domestica, Syritta spinigera, Dirhinoides wohlfahrtia, Bracon hebetor, Devorgilla canescens, Anisopteromalus calandrae, Pachycrepoides vendemia, Carpophilus hemipterus, Carpophilus dimidiatus, Carpophilus obsoletus, Lasioderma serricorne, Gibbium psylloides, Haemophlaeus ater, Oryzaephilus surinamensis, Tenebroides mauritanicus, Tribolium castaneum, Tribolium confusum and Dermestes maculates (El-Sherif, 1971; Aboul-
Zahab, 1976; Abd-El-Fattah, 1980; Marei, 1985 \& El-Bolok et al., 1990). Only six of these species (Xylocoris galactinus, Eumerus amoenus, Eumerus vestitus, Atherigona orientalis, Musca domestica and Dirhinoides wohlfahrtia) could be recorded on stored onion bulbs during the current survey while seven species are first records namely: Cadra cautella, Sciara kairensis, Saprinus chalcites, Carpophilus humeralis, Carpophilus immaculatus, Paederus alfierii and Clitobius oblongiusculus.

In Egypt, Aboul-Zahab (1976) stated that stored onions are subject to infestation with two Lepidopterous pests (Cadra cautella and Plodia interpunctella), two Dipterous pests (Atherigona orientalis and Eumerus amoenus) and three Coleopterous pests (Carpophilus hemipterus, Carpophilus dimidiatus and Lasioderma serricorne). Abd-El-Fattah (1980) surveyed the insects infesting onion bulbs in store and recorded 19 species the most destructive of which was E.amoenus. Marei (1985) pointed out that stored onion bulbs were attacked by Eumerus amoenus, Delia alliaria, Cryptoblabes gnidiella and Carpophilus hemipterous from June to August. El-Bolok et al. (1990) reported that the insect pests occurring on stored onion bulbs, which belonged to 19 genera from 13 families and 5 orders, were accompanied with a group of natural enemies belonging to 5 genera from 5 families and 2 orders.

\section{REFERENCES}

Abd-El-Fattah T. A. (1980). Factors affecting the insect population during the storage of onion bulbs. M. Sc. Thesis, Fac. Agric., AlAzher Univ., Egypt, 94 pp.

Abd-El-Wahab A. S. (2004). Insects and insect borne viruses associated with Alliaceae crops in Egypt. Ph. D. Thesis, Fac. Agric., Cairo Univ., Egypt, 250 pp.

Aboul-Zahab A. O. (1976). Biological and ecological studies on certain insect pests infesting onion in A. R. E. M. Sc. Thesis, Fac. Agric., Ain Shams Univ., Egypt, 66 pp.

Ahn S. B., Lee S. B. and Cho W. S. (1991). Leaf feeding insect pests and their damage on welsh onion and shallot fields in Chonrabukdo and Chonranamdo Districts. Research Reports of the Rural Development Administration Crop Protection, 33 (1): 6673.

Aihara E., Matsumoto N. and Muramatsu T. (1985). Dipterous insects detected on imported onion bulbs with a tentative 
pictorial key to larvae. Research Bulletin of the Plant Protection Service, Japan, 21: 7580.

Chernenko V. L. and Chernenko K. M. (2004). Onion pests from the east of forest-steppe of Ukraine. Nowosci-Warzywnicze, 38: 95100.

Ciociola-Jr A. I., Franca F. H. and Ciociola A. I. (2002). Pests associated with onion crops and their control. Informe-Agropecuario, 23 (218): 68-74.

Duchovskiene L. (2003). Dynamics of pest harmfulness in onion crop depending on growing technique. Sodininkyste ir Darzininkyste, 22 (1): 153-163.

El-Bolok M. M., Ismail I. I. and El-Shabrawy H. A. (1990). Survey and relative abundance of insects attacking onion in field and store with the accompanied natural enemies at Giza and Assuit regions. Annals of Agric. Sc., Moshtohor, 28 (3): 1791-1804.

El-Shabrawy H. A. (1996). The role of carbon dioxide and irradiation in reducing the infestation of two onion bulb flies, Eumerus amoenus Loew. and Eumerus vestitus Bezzi. (Diptera: Syrphidae). Ph. D. Thesis, Fac. Agric., Cairo Univ., Egypt, 156 pp.

El-Sherif A. R. A. (1971). Studies on insects infesting onion and garlic in field and storage. Ph. D. Thesis, Fac. Agric., Cairo Univ., Egypt, 279 pp.

Gupta R. P., Srivastava K. J. and Pandey U. B. (1991). Management of onion diseases and insect pests in India. Onion Newsletter for the Tropics, 3: 15-17.

Haydar M. F. and Sherif L. S. (1987). Ecological aspects and developing method of onion pest control. Bull. Soc. Ent. Egypt, Economic Series, 16: 119-126.

Ibrahim M. M., Koura A. and El-Halfawy M. (1970). Ecological and biological studies on some insects infesting dried onions in U. A. R. Agric. Res. Rev., Cairo, 48 (1): 59-63.

Khalil F. M., El-Sebae A. H. and Karaman G. A. (1971). Some ecological studies on Thrips tabaci Lind. Assiut J. Agric. Sci., 2 (1): 197-206.

Klein-Krautheim F. (1934). The onion fly, Eumerus strigatus, as a pest of beet. Anz. Schadlingsk., 10 (9): 99-101. (c. f. R. A. E., 22: 661-662, 1934).

Marcos-Garcia M. A. (1990). New species of Eristalinae for the Iberian fauna (Diptera, Syrphidae). Nouvelle Revue Entomologie, 7 (3): 317-323.

Marei S. S. (1985). Studies on natural enemies of stored onion and garlic pests. Ph. D. Thesis, Fac. Agric., Cairo Univ., Egypt, 101 pp.

Mesic, A. and Baric, J. I. (2004). Diptera pests on onion vegetables in Croatia. EntomologiaCroatica, 8 (1/2): 45-56.

Paulauskyte L. (1999). Most serious onion pests and search for effective control means. Sodininkyste ir Darzininkyste, 18 (3): 228234.

Szwejda J. (1998). Threat of onion plantations with pests, especially Diptera. Biuletyn Warzywniczy, 48: 57-64.

Szwejda J. (2005). Pests threatening onion in Poland. Nowosci-Warzywnicze, 40: 53-59.

Thiramurthi S., Udayasoorian C. and Balamurugan P. (1989). Insects affecting onion flowers. Seeds and Farms, 15 (2): 23 24. 


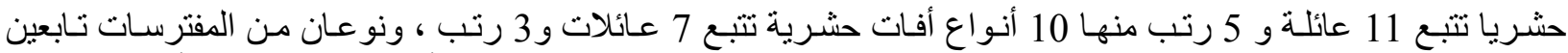

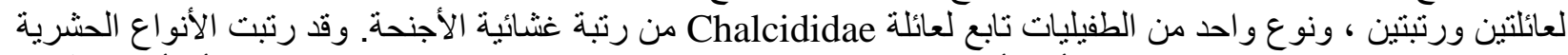

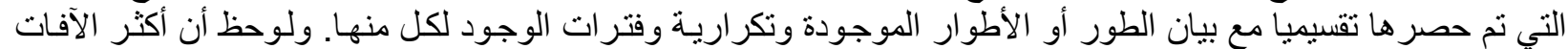

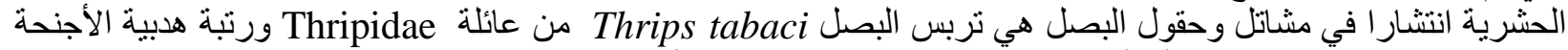

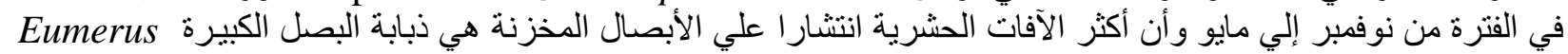
Symoenus

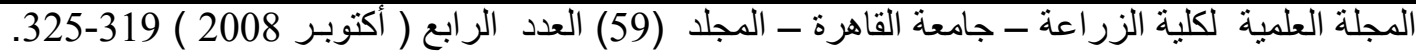

